\title{
PENERAPAN METODE KOOPERATIF MODEL TGT (TEAM GAMES TOURNAMENT) SEBAGAI ALTERNATIF MENINGKATKAN PRESTASI BELAJAR MATEMATIKA PADA SISWA KELAS V SD NEGERI 200410 SIMAPIL-APIL PADANGSIDIMPUAN TAHUN PELAJARAN 2016/2017
}

\author{
SARUDDIN HARAHAP, S.Pd \\ NIP: 196806281989091001 \\ Email: saripuddin88@gmail.com
}

\begin{abstract}
abstrak
Matematika merupakan suatu bahan kajian yang memiliki objek abstrak dan dibangun melalui proses penalaran deduktif, yaitu kebenaran suatu konsep diperoleh sebagai akibat logis dari kebenaran sebelumnya sudah diterima, sehingga keterkaitan antar konsep dalam matematika bersifat sangat kuat dan jelas. Dalam pembelajaran matematika agar mudah dimengerti oleh siswa, proses penalaran deduktif untuk menguatkan pemahaman yang sudah dimiliki oleh siswa. Tujuan pembelajaran matematika adalah melatih cara berfikir secara sistematis, logis, kritis, kreatif dan konsisten.
\end{abstract}

Penelitian ini berdasarkan permasalahan: (a) Bagaimanakah peningkatan prestasi belajar siswa dengan diterapkannya metode pembelajaran kooperatif model TGT? (b) Bagaimanakah pengaruh metode pembelajaran kooperatif model TGT terhadap motivasi belajar siswa?

Sedangkan tujuan dari penelitian ini adalah: (a) Ingin mengetahui peningkatan prestasi belajar siswa setelah diterapkannya metode pembelajaran kooperatif model TGT. (b) Ingin mengetahui pengaruh motivasi belajar siswa setelah diterapkan metode pembelajaran kooperatif model TGT.

Penelitian ini menggunakan penelitian tindakan (action research) sebanyak tiga putaran. Setiap putaran terdiri dari empat tahap yaitu: rancangan, kegiatan dan pengamatan, refleksi, dan refisi. Sasaran penelitian ini adalah siswa kelas V SD data yang diperoleh berupa hasil tes formatif, lembar observasi kegiatan belajar mengajar.

Dari hasil analis didapatkan bahwa prestasi belajar siswa mengalami peningkatan dari siklus I sampai siklus III yaitu, siklus I (66,67\%), siklus II (77,78\%), siklus III $(88,89 \%)$.

Kesimpulan dari penelitian ini adalah metode kooperatif model TGT dapat berpengaruh positif terhadap motivasi belajar Siswa serta model pembelajaran ini dapat digunakan sebagai salah satu alternatif pembelajaran matematika.

Kata Kunci: pembelajaran matematika, metode kooperatif model TGT 


\section{PENDAHULUAN}

Matematika merupakan suatu bahan kajian yang memiliki objek abstrak dan dibangun melalui proses penalaran deduktif, yaitu kebenaran suatu konsep diperoleh sebagai akibat logis dari kebenaran sebelumnya sudah diterima, sehingga keterkaitan antar konsep dalam matematika bersifat sangat kuat dan jelas.

Dalam pembelajaran matematika agar mudah dimengerti oleh siswa, proses penalaran deduktif untuk menguatkan pemahaman yang sudah dimiliki oleh siswa. Tujuan pembelajaran matematika adalah melatih cara berfikir secara sistematis, logis, kritis, kreatif dan konsisten.

Pembelajaran matematika tidak juga tidak lagi mengutamakan pada penyerapan melalui pencapaian informasi, tetapi lebih mengutamakan pada pengembangan kemampuan dan pemrosesan informasi. Untuk itu aktivitas peserta didik perlu ditingkatkan melalui latihan-latihan atau tugas matematika dengan bekerja kelompok kecil dan menjelaskan ide-ide kepada orang lain. (Hartoyo, 2000: 24).

Langkah-langkah

tersebut

memerlukan partisipasi aktif dari siswa. Untuk itu perlu ada metode pembelajaran yang melibatkan siswa secara langsung dalam pembelajaran. Adapun metode yang dimaksud adalah metode pembelajaan kooperatif. Pembelajaran kooperatif adalah suatu pengajaran yang melibatkan siswa bekerja dalam kelompok-kelompok untuk menetapkan tujuan bersama. Felder, (1994: 2).

Pembelajaran kooperatif lebih menekankan interaksi antar siswa. Dari sini siswa akan melakukan komunikasi aktif dengan sesama temannya. Dengan komunikasi tersebut diharapkan siswa dapat menguasai materi pelajaran dengan mudah karena "siswa lebih mudah memahami penjelasan dari kawannya dibanding penjelasan dari guru karena taraf pengetahuan serta pemikiran mereka lebih sejalan dan sepadan". (Sulaiman dalam Wahyuni 2001: 2).

Penelitian juga menunjukkan bahwa pembelajaran kooperatif memiliki dampak yang amat positif terhadap siswa yang rendah hasil belajarnya. (Nur, 1996: 2).

Pete Tschumi dari Universitas Arkansas Little Rock memperkenalkan suatu ilmu pengetahuan pengantar pelajaran komputer selama tiga kali, yang pertama siswa bekerja secara individu, dan dua kali secara kelompok. Dalam kelas pertama hanya $36 \%$ siswa yang mendapat nilai $\mathrm{C}$ atau lebih baik, dan dalam kelas yang bekerja secara kooperatif ada 58\% dan 65\% siswa yang mendapat nilai $\mathrm{C}$ atau lebih baik (Felder, 1994:14).

Berdasarkan paparan tersebut diatas maka peneliti ingin mencoba Penerapan Metode Kooperatif Model TGT (Team Games Tournament) Sebagai Alternatif Meningkatkan Prestasi Belajar Matematika Pada Siswa Kelas melakukan penelitian dengan judul "Penerapan Metode Kooperatif Model TGT (Team Games Tournament) Sebagai Alternatif Meningkatkan Prestasi Belajar Matematika Pada Siswa kelas V SD Negeri $200410 \quad$ Simapil-Apil Padangsidimpuan Tahun Pelajaran 2016/2017"

\section{Metode Penelitian}

Penelitian ini menggunakan Penelitian Tindakan Kelas (PTK). Menurut Tim Pelatih Proyek PGSM, PTK adalah suatu bentuk kajian yang bersifat reflektif oleh pelaku tindakan yang dilakukan untuk meningkatkan kemantapan rasional dari tindakan mereka dalam melaksanakan tugas, memperdalam pemahaman terhadap tindakan-tindakan yang dilakukan itu, serta 
memperbaiki kondisi dimana praktek pembelajaran tersebut dilakukan (dalam Mukhlis, 2000: 3).

Sedangkah menurut Mukhlis (2000: 5) PTK adalah suatu bentuk kajian yang bersifat sistematis reflektif oleh pelaku tindakan untuk memperbaiki kondisi pembelajaran yang dilakukan.

Adapun tujuan utama dari PTK adalah untuk memperbaiki/meningkatkan pratek pembelajaran secara berkesinambungan, sedangkan tujuan penyertaannya adalah menumbuhkan budaya meneliti di kalangan guru (Mukhlis, 2000: $5)$.

Sesuai dengan jenis penelitian yang dipilih, yaitu penelitian tindakan, maka penelitian ini menggunakan model penelitian tindakan dari Kemmis dan Taggart (dalam Sugiarti, 1997: 6), yaitu berbentuk spiral dari sklus yang satu ke siklus yang berikutnya. Setiap siklus meliputi planning (rencana), action (tindakan), observation (pengamatan), dan reflection (refleksi). Langkah pada siklus berikutnya adalah perncanaan yang sudah direvisi, tindakan, pengamatan, dan refleksi. Sebelum masuk pada siklus 1 dilakukan tindakan pendahuluan yang berupa identifikasi permasalahan.

\section{HASIL PENELITIAN DAN PEMBAHASAN}

\section{Siklus I}

Tabel 4.4. Rekapitulasi Hasil Tes Formatif Pada Siklus I

\begin{tabular}{|c|l|c|}
\hline No & \multicolumn{1}{|c|}{ Uraian } & $\begin{array}{c}\text { Hasil } \\
\text { Siklus I }\end{array}$ \\
\hline 1 & $\begin{array}{l}\text { Nilai rata-rata tes } \\
\text { formatif } \\
2\end{array}$ & $\begin{array}{l}\text { Jumlah siswa yang tuntas } \\
\text { belajar } \\
\text { Persentase } \\
\text { belajar }\end{array}$ \\
\hline
\end{tabular}

Dari tabel di atas dapat dijelaskan bahwa dengan menerapkan metode pembelajaran kooperatif model TGT diperoleh nilai rata-rata prestasi belajar siswa adalah 66,30 dan ketuntasan belajar mencapai $66,67 \%$ atau ada 16 siswa dari 23 siswa sudah tuntas belajar. Hasil tersebut menunjukkan bahwa pada siklus pertama secara klasikal siswa belum tuntas belajar, karena siswa yang memperoleh nilai $\geq 65$ hanya sebesar $66,67 \%$ lebih kecil dari persentase ketuntasan yang dikehendaki yaitu sebesar $85 \%$. Hal ini disebabkan karena siswa masih merasa baru dan belum mengerti apa yang dimaksudkan dan digunakan guru dengan menerapkan metode pembelajaran kooperatif model TGT.

\section{Siklus II}

Tabel 4.8. Rekapitulasi Hasil Tes Formatif Pada Siklus II

\begin{tabular}{|c|l|c|}
\hline No & \multicolumn{1}{|c|}{ Uraian } & $\begin{array}{c}\text { Hasil } \\
\text { Siklus II }\end{array}$ \\
2 & $\begin{array}{l}\text { Nilai rata-rata tes } \\
\text { formatif } \\
3\end{array}$ & $\begin{array}{l}\text { Jumlah siswa yang } \\
\text { tuntas belajar } \\
\text { Persentase ketuntasan } \\
\text { belajar }\end{array}$ \\
\hline
\end{tabular}

Dari tabel di atas diperoleh nilai rata-rata prestasi belajar siswa adalah 73,70 dan ketuntasan belajar mencapai $77,78 \%$ atau ada 18 siswa dari 23 siswa sudah tuntas belajar. Hasil ini menunjukkan bahwa pada siklus II ini ketuntasan belajar secara klasikal telah mengalami peningkatan sedikit lebih baik dari siklus I. Adanya peningkatan hasil 
belajar siswa ini karena setelah guru menginformasikan bahwa setiap akhir pelajaran akan selalu diadakan tes sehingga pada pertemuan berikutnya siswa lebih termotivasi untuk belajar. Selain itu siswa juga sudah mulai mengerti apa yang dimaksudkan dan diinginkan guru dengan menerapkan metode pembelajaran kooperatif model TGT.

\section{Siklus III}

Tabel 4.12. Hasil Tes Formatif Siswa pada Siklus III

\begin{tabular}{|c|l|c|}
\hline No & \multicolumn{1}{|c|}{ Uraian } & $\begin{array}{c}\text { Hasil } \\
\text { Siklus } \\
\text { III }\end{array}$ \\
\hline 1 & $\begin{array}{l}\text { Nilai rata-rata tes } \\
\text { formatif }\end{array}$ & 80,74 \\
3 & $\begin{array}{l}\text { Jumlah siswa yang } \\
\text { tuntas belajar } \\
\text { Persentase ketuntasan } \\
\text { belajar }\end{array}$ \\
\hline
\end{tabular}

Berdasarkan tabel diatas diperoleh nilai rata-rata tes formatif sebesar 80,74 dan dari 23 siswa yang telah tuntas sebanyak 21 siswa dan 2 siswa belum mencapai ketuntasan belajar. Maka secara klasikal ketuntasan belajar yang telah tercapai sebesar $88,89 \%$ (termasuk kategori tuntas). Hasil pada siklus III ini mengalami peningkatan lebih baik dari siklus II. Adanya peningkatan hasil belajar pada siklus III ini dipengaruhi oleh adanya peningkatan kemampuan guru dalam menerapkan metode pembelajaran kooperatif model TGT membuat siswa menjadi lebih terbiasa dengan pembelajaran seperti ini sehingga siswa lebih mudah dalam memahami materi yang telah diberikan.

\section{Pembahasan}

1. Ketuntasan Hasil belajar Siswa

Melalui hasil penelitian ini menunjukkan bahwa pembelajaran kooperatif model TGT memiliki dampak positif dalam meningkatkan prestasi belajar siswa. Hal ini dapat dilihat dari semakin mantapnya pemahaman siswa terhadap materi yang disampaikan guru (ketuntasan belajar meningkat dari sklus I, II, dan III) yaitu masing-masing $66,67 \%$, 77,78\%, dan $88,89 \%$. Pada siklus III ketuntasan belajar siswa secara klasikal telah tercapai.

2. Kemampuan Guru dalam Mengelola Pembelajaran

Berdasarkan analisis data, diperoleh aktivitas siswa dalam proses metode pembelajaran kooperatif model TGT dalam setiap siklus mengalami peningkatan. Hal ini berdampak positif terhadap prestasi belajar siswa yaitu dapat ditunjukkan dengan meningkatnya nilai rata-rata siswa pada setiap siklus yang terus mengalami peningkatan.

3. Aktivitas Guru dan Siswa Dalam Pembelajaran

Berdasarkan analisis data, diperoleh aktivitas siswa dalam proses pembelajaran fisika pokok bahasan Pengukuran dengan metode pembelajaran kooperatif model TGT yang paling dominant adalah bekerja dengan menggunakan alat/media, mendengarkan/memperhatikan penjelasan guru, dan diskusi antar siswa/antara siswa dengan guru. Jadi 
dapat dikatakan bahwa aktivitas siswa DAFTAR PUSTAKA

dapat dikategorikan aktif.

Sedangkan untuk aktivitas guru selama pembelajaran telah melaksanakan langkah-langkah metode pembelajaran kooperatif model TGT dengan baik. Hal ini terlihat dari aktivitas guru yang muncul di antaranya aktivitas membimbing dan mengamati siswa dalam mengerjakan kegiatan LKS/menemukan konsep, menjelaskan materi yang sulit, memberi umpan balik/evaluasi/tanya jawab dimana prosentase untuk aktivitas di atas cukup besar.

\section{Kesimpulan}

Dari hasil kegiatan pembelajaran yang telah dilakukan selama tiga siklus, dan berdasarkan seluruh pembahasan serta analisis yang telah dilakukan dapat disimpulkan sebagai berikut:

1. Pembelajaran dengan kooperatif model TGT memiliki dampak positif dalam meningkatkan prestasi belajar siswa yang ditandai dengan peningkatan ketuntasan belajar siswa dalam setiap siklus, yaitu siklus I $(66,67 \%)$, siklus II $(77,78 \%)$, siklus III $(88,89 \%)$.

2. Penerapan metode pembelajaran kooperatif model TGT mempunyai pengaruh positif, yaitu dapat meningkatkan motivasi belajar siswa yang ditunjukan dengan hasil wawancar dengan beberapa siswa, rata-rata jawaban menyatakan bahwa siswa tertarik dan berminat dengan metode pembelajaran kooperatif model TGT sehingga mereka menjadi termotivasi untuk belajar.
Ali, Muhammad. 1996. Guru Dalam Proses Belajar Mengajar. Bandung: Sinar Baru Algesindon.

Arikunto, Suharsimi. 1993. Manajemen Mengajar Secara Manusiawi. Jakarta: Rineksa Cipta.

Arikunto, Suharsimi. 1998. Prosedur Penelitian Suatu Pendekatan Praktek. Jakarta: Rineksa Cipta.

Arikunto, Suharsimi. 2001. Dasar-dasar Evaluasi Pendidikan. Jakarta: Bumi Aksara.

Arsyad, Azhar. 1997. Media Pembelajaran. Jakarta: PT. RajaGrafindo Persada.

Combs. Arthur. W. 1984. The Profesional Education of Teachers. Allin and Bacon, Inc. Boston.

Dahar, R.W. 1989. Teori-teori Belajar. Jakarta: Erlangga.

Departemen Pendidikan dan Kebudayaan, 1994. Petunjuk Pelaksanaan Proses Belajar Mengajar, Jakarta. Balai Pustaka. 